\title{
A Note on the 2017 Landmark US Ruling on the Constitutionality of Prohibiting the Trademarking of Potentially Disparaging Names
}

\author{
I. M. Nick
}

Germanic Society for Forensic Linguistics, Flensburg, Germany

The Lanham Act was enacted by the US Congress in 1946 with the overall purpose of regularizing the nation's registration and use of trademarks. Despite undergoing a number of amendments since its enactment, for the past 70 years, the Act has continued to provide key federal protections against not only the unlawful or deceptive use of trademarks. It also strictly forbad the registration of marks that reasonably could be considered immoral, scandalous, contemptuous, or disparaging. Though hailed by some as an important protection against hateful speech in the public marketplace, others have questioned whether the statute violates the constitutional right to Freedom of Speech. This year, the US Supreme Court issued a ruling that put an official end to this legal controversy. This article provides a detailed description of the case that led to this landmark decision and discusses some of the potential implications for trademarking potentially disparaging brand names.

KEYWORDS Lanham Act, trademark, US Constitution, brand names, Supreme Court, freedom of speech.

In 2006, the 25-year-old Simon Tam founded an all-Asian post-punk revival band in Portland, Oregon. It did not take long before the group gained a foothold throughout the Pacific Northwest music scene for its raucous concerts. In recent years, the band has also gone on to win international notoriety. The reason for the media attention is not, however, the band's self-described blend of "Chinatown Dance Rock" but its uncommon name: The Slants.

In a 2017 interview with National Public Radio, Tam revealed why the band purposefully selected the provocative name. As Tam explained, he and his fellow band members grew up in the United States with the belief that "having slanted eyes

This article has been republished with minor changes. These changes do not impact the academic content of the article. 
was always considered a negative thing [... Kids would pull their eyes back in a slanteyed gesture to make fun of us" (Chow 20I7, para. 6). The bandmembers selected the bandname The Slants in a conscientious effort to transform the meaning of the slur into "something that was powerful, something that was considered beautiful or a point of pride instead" (Chow 20I7, para 6). So far so good. That is until 5 March 20I0, when the band first attempted to register its moniker with the United States Patent and Trademark Office (USPTO Serial \# 77952263). ${ }^{\text {I }}$

The USPTO denied the request to register the name as an official trademark on the grounds that the "Applicant's Mark is disparaging to persons of Asian ethnicity" (2OII, 2) ${ }^{2}$ Tam appealed the decision arguing that the bandname was in fact "is a positive term of self-reference that promotes cultural pride and recognition $[\ldots]$ " that "had been widely embraced by the Asian community" (2OI I , 8). ${ }^{3}$ Despite this argumentation, on 6 January 2OI2, the USPTO upheld its original decision and once again rejected the petition on the grounds that "the applied-for mark consists of or includes matter which may disparage or bring into contempt or disrepute persons, institutions, beliefs of national symbols" 4

The legal basis came from Section 2(a) of the US Trademark Act of 1946. Better known as "the Lanham Act", the federal statute was passed by the US Congress on 5 July I946. Explained briefly, this statute prohibits the registration of any trademark which may consist of or comprise "immoral, deceptive, or scandalous matter" that may cause disparagement (USPTO 20I3, 9). Importantly, the Act fails to explicitly codify what precisely is meant by the term "disparagement" (Battersby and Grimes 20I7). For that reason, USPTO decisions are made on a case-by-case basis. In the case of The Slants, the Applicant's own words may have helped to establish a case of disparagement. In researching the case, the responsible Examining Attorney located several news items in the print and social media where Tam openly had described the term "slant" as a racial slur against persons of Asian(-American) descent. For example, in an interview with Northwest Asian Weekly on I7 March 20I I, Tam stated that "one of the first things people say is that we have slanted eyes [...] I thought, 'what a great way to reclaim that stereotype and take ownership of it' [...] take away power from those who try to use it as a term of hate" (Harris 20II, para 7). According to the Examining Attorney, with such statements, the Applicant essentially admitted that the term "slants" is "offensive and derogatory to a substantial composite of Asian-Americans" 5 For the USPTO, this was an open and shut case. Tam and his legal team vehemently disagreed and appealed the decision; but they changed the direction of their argumentation. The ultimate question, they said, was not whether The Slants is offensive but whether the band had a constitutional right to name itself under the First Amendment. On 22 December 2015, the United States Court of Appeals for the Federal Circuit issued its ruling on this question:

Mr. Simon Shiao Tam named his band THE SLANTS to make a statement about racial and cultural issues in this country. With his band name, Mr. Tam convey more about our society than many volumes of undisputedly protected speech. [...] Many of the [trade]marks rejected as disparaging convey hurtful speech that harms members of oft-stigmatized communities. But the First Amendment protects even hurtful speech. The government cannot refuse to register disparaging marks because it disapproves of the expressive messages conveyed by the marks. It cannot refuse to register marks because it concludes that such marks will be disparaging to others. $(4)^{6}$ 
With this ruling, the District Court not only granted Tam the right to register the name The Slants as an official trademark; it also explicitly concluded that Section 2(a) of the Lanham Act was unconstitutional. This time it was the US government that contested the decision. For many observers, this legal conflict would ideally be resolved by the Supreme Court of the United States (SCOTUS). Despite this fact, there was no guarantee of course that the SCOTUS would agree to adjudicate the case. Each judicial term, between seven to nine thousand petitions are filed either for possible adjudication. Given that volume, the Court is highly selective in the cases it elects to hear. As a general rule, it has displayed a preference for appellate cases that lie at the heart of a Constitutional question of great social and legal import. In the Winter of 20I7, the SCOTUS accepted arguments in the case the United States Patent and Trademark Office v. Tam. By I9 June 20I7, the Court issued its final judgment. The Court praised the USPTO for "evenhandedly" prohibiting marks that might "damn Democrats and Republicans, capitalists and socialists, and those arrayed on both sides of every possible issue." $(22)^{7}$. However, the fact that the USPTO's determination of disparagement necessarily varies with one's vantage point means that the Office's practice is tantamount to "viewpoint discrimination" which is forbidden. Consequently, the Court ruled in an 8-o decision that the disparagement clause of the Lanham Act did indeed violate the Free Speech Clause of the First Amendment. ${ }^{8}$ The Court's ruling hit like a tsunami, starting out slowly and then rising to gigantic proportions as the potential repercussions became clear. The judgment not only bodes well for the retention of trademarked names that have long been criticized as being offensive to minority groups (e.g. Quaker Oats, Eskimo Pies, Aunt Jemima, Uncle Ben's) ${ }^{9}$. Thanks to this decision, the US marketplace might also find itself deluged with an unstoppable wave of trademarks that many buyers may find vulgar, obscene, immoral, offensive, and downright disparaging. Even a cursory look at the USPTO trademark databank ${ }^{\mathrm{IO}}$ reveals a number of applications for names that previously would have stood an excellent chance of being automatically rejected under the Lanham Act.

As Table I demonstrates, the ruling has implications far beyond names and naming in the music business - an industry which some might argue regularly and quite happily crosses the prescriptive lines of good taste. The SCOTUS decision may also have direct legal implications for one of the most reviled names in US athletics, the Redskins. ${ }^{\text {II }}$ Before the ruling, the days of the Washingtonian football team's moniker seemed numbered. This perception was fueled, in part, by the franchise's impressive streak of key legal losses. On 2 April I999, for example, a three-judge panel of the USPTO ordered the cancellation of seven trademarks held by the National Football League (NFL) team, including the team's name (Guggenheim 1999). Although this decision did not prevent the team from using its name, it would prohibit the franchise from invoking federal law to prevent other vendors from using the name to sell its merchandise (Hughey 2004). To prevent this potential loss of revenue, the franchise, ProFootball, Inc., waged a no holds-barred battle to have the USPTO decision reversed. In 2003, the team scored a temporary win when the decision was overturned on appeal; but then "in 2005, the United States Court of Appeals for the District of Columbia reversed and remanded the case back to the district court" (Rasul 20I 5, I65). Shortly thereafter, a petition was filed by six Native Americans (the Blackhorse Defendants) to once again cancel the Washingtonian team's trademark registrations. In support of the 
TABLE 1

SAMPLING OF POTENTIALLY DISPARAGING NAMES UNDER APPLICATION WITH THE USPTO (2016-2017)

\begin{tabular}{lllll}
\hline & Trademark name & Serial number & Filing date & Goods/service \\
\hline 1 & Nigger Please & $87,495,357$ & 19 June 2017 & shirts \\
2 & Sambo & $87,099,194$ & 11 July 2016 & multimedia software \\
3 & 1st Class White Trash & $87,399,663$ & 5 April 2017 & t-shirts \\
4 & Yid-Lid & $87,420,347$ & 21 April 2017 & kippahs(yarmulkes) \\
5 & Sweet Pussy Candy & $87,427,225$ & 27 April 2017 & candy \\
6 & Yoga Whores & $87,114,913$ & 25 July 2016 & t-shirts, tops, \& bottoms \\
7 & Dick's Nut Sack & $87,051,296$ & 26 May 2016 & Baseball caps, hats, sweat shirts \\
8 & Functioning Retard & $86,887,981$ & 27 January 2016 & clothing, coffee mugs, \\
& Not all Whites are Racist & $87,129,814$ & 7 August 2016 & (t-)shirts \\
9 & $\begin{array}{l}\text { Noll Police are Criminals } \\
\text { All Muslims are Terrorist }\end{array}$ & & & \\
10 & Hairy Hindu & $87,443,102$ & 9 May 2017 & non-electric razors \\
\hline
\end{tabular}

Defendants, the National Congress of American Indians (NCAI) produced empirical evidence to demonstrate that the term redskins was negatively perceived by a substantial composite of the Native American community. ${ }^{12}$ In the face of such evidence, despite being one of the wealthiest teams in the NFL (Forbes Magazine 20I6), the team's chances of winning the courtroom battle did not look good. Those appearances were by no means deceiving. In June 20I4, the Trademark Trial and Appeal Board once again cancelled the team's trademarks on the grounds that they were in violation of the Lanham Act. Undaunted, Pro-Football, Inc. appealed again on the grounds that Section 2(a) of the Lanham Act was unconstitutional. This time the case was heard by the United States District Court of the Eastern District of Virginia. After much deliberation, the Court denied the team's "motion for Summary Judgment on Constitutional Claims" and "GRANT[ED] the cross-motions for summary judgment filed by Blackhorse Defendants and the United States of America" (United States District Court for the Eastern District of Virginia: Alexandria Division 2015, 2). In short, the football franchise lost. This decision was celebrated by civil rights and Native American activists. As NCAI President Brian Cladossby proclaimed in reaction to the Virginia Court's ruling: "The federal courts have recognized that the use of the R-word is offensive and degrading to our identity as Native people" (2015, para 3). For many observers, this decision seemed to be the final death Nell for the team's name that was until The Slants and the SCOTUS ruling. Now, the chances are not only exceedingly good that the franchise's trademarks will be re-instated. By virtue of this ruling, Pro-Football, Inc. also has extremely powerful legal ammunition for continuing to use its controversial name. No matter how many people the name may offend (or disparage), its use would seem to be constitutionally protected under the Freedom of Speech (Heitner 2017). No sooner was the SCOTUS decision announced, did Washington team proclaim its legal victory. As Pro-Football, Inc. attorney, Lisa Blatt, pronounced in a press statement released on the day of the ruling:

The Team is thrilled with today's unanimous decision as its resolves the Redskins' longstanding dispute with the government. The Supreme Court indicated the Team's position that the First Amendment blocks the government from denying or cancelling a trademark registration based on the government's opinion. (Freed 2017, I2) 
The statement issued by Team Owner Dan Synder was much shorter but no less jubilant: "I am THRILLED! Hail to the Redskins" (Phillips 20I7, para I). As Hopkins and Joraanstad (2015) noted: "Even though Dan Snyder remains adamant that he has no intention of changing the name, if the tide of public opinion continues in opposition to the name, the fans and sponsors may have the ultimate say: with their wallets" (296). In a 20I4 article for the Journal of Intellectual Property Law, John Thomas made a similar prediction: "[o]ffensive or disparaging marks are generally bad for business, since people who are offended will not support the offensive product or service" (2014, 436). There is much evidence that speaks in favor of this argumentation. Over the years, thanks to continuing efforts by civil rights activists and supporters, sensitivity to minority issues has substantially increased (Lindsay 2008). The result has been a slow but steady voluntary movement away from potentially offensive trademarked names (NCAA 2005). ${ }^{\mathrm{I}} \mathrm{In}$ comparison to this nationwide shift, the Washingtonian team name has become almost anachronistic: a jarring reminder of the nation's past. As Dan Snyder defiantly stated four years ago in a USA Today interview, Pro-Football, Inc. has no plans to follow this onomastic trend. "We will never change the name [...] It's that simple. NEVER - you can use caps" (Brady 2013). To a certain extent this aversion to change is nothing new for the Washingtonian team. In I96I, it stood alone as the last remaining team in the entire NFL without a single African-American player on its roster (Smith 20I I).

For their own part, The Slants is simply happy to have won a nearly Io-year-long court battle that many had written off as hopeless ${ }^{\mathrm{I} 4}$. Days after the ruling, the band published a statement on their website "Now, Americans can decide who should prevail in the marketplace of ideas rather than a lone examining attorney. Oppressed groups will no longer have their identities shaped by the sensibilities of dominant ones" (own emphasis added) (http://www.theslants.com/). Despite Pro-Football, Inc.'s repeated efforts to jump on The Slants band wagon, there are clear difference between the two cases - one of the most important being is "who is doing the naming" (Lindsay 2008, 214). In the case of The Slants, the name was chosen by a disadvantaged minority group to label and empower themselves. In the case of the football team, the name was selected by a White Southerner with no known Native American ancestry who regularly humiliated Native American players by requiring them "to put on war paint before a fame and do a little Indian dance to entertain the paying customer" (Smith 20II, I2). In the case of The Slants, the autonym is source of cultural pride and unity; in the case of the football team, the name has been a source of cultural division and political protest. Given those linguistic, philosophical, and political differences, The Slants has consistently attempted to distance themselves from the football team and its objectives. As Tam revealed in a New York Times interview (Jeong 20I7), given a full six months before the Supreme Court issued its final verdict, he "does not care for the Redskins or the team's owner, Dan Snyder" (para. 22). In his opinion, that name has "a long history of oppression" (Jeong 2017, para. 22). The fact that the band's hard-fought onomastic victory may now be inextricably tied to the Washington football team's name is a source of deep frustration to the band. Nevertheless, Tam remains adamant that censorship is not an acceptable way to combat societal discrimination. This position is shared by American Civil Liberties Union (ACLU) Senior Staff Attorney Lee Rowland (20I7) who wrote on 
the day of the SCOTUS ruling: "there's no way to lawfully censor speech that offends us without allowing the government the power to censor speech that offends anyone" (para. I). So now that 70 years of governmental onomastic controls have been removed, what is there to protect us from hurtful trademarked names that degrade and offend? According to a sage article written by Nuessel (I994), the answer is not easy but simple: a deep altruistic "sensitivity and respect for fellow human beings" (I I4).

\section{Notes}

I. For full documentation on this first application, see USPTO serial number: $77952263<$ http:// ttabvue.uspto.gov/ttabvue/v?qs=77952263 $>$.

2. USPTO serial number 77952263 , Document 4 : $<$ http://ttabvue.uspto.gov/ttabvue/v?qs=77952263>.

3. USPTO serial number 77952263 , Document 2: $<$ http://ttabvue.uspto.gov/ttabvue/v?pno=779 $52263 \&$ pty $=$ EXA\&eno $=4>$.

4. USPTO serial number 85472044 , Document 9: $<$ http://ttabvue.uspto.gov/ttabvue/v?pno=85472044 \&pty $=$ EXA\&eno $=9>$.

5. USPTO serial number 77952263, Document 5: $<$ http://ttabvue.uspto.gov/ttabvue/v?pno=77952 263 \& 2 ty $=$ EXA\&eno $=5>$.

6. For the full US Court of Appeals for the Federal Circuit decision, see: https://e-foia.uspto.gov/ Foia/RetrievePdf?system=FCA\& $\&$ flNm $=I 4-I$ 203_2

7. The ruling can be found here: <https://www. supremecourt.gov/opinions/I 6 pdf/I 5-I 293 _ IOI 3.pdf $>$.

8. Although some legal scholars anticipated the SCOTUS decision, others contended that the Lanham Act was an imperfect but practical protection (e.g. Kiser 20II; Stern I999). As Bonadio (2015) reasoned: "judges have the right and duty to restrict such freedom by refusing registration if that is necessary to protect competing interests, including: morality, decency, public order, and minorities' rights" (60).

9. For a historical discussion of trademarks and US racism, see Hinrichsen $20 \mathrm{I} 2$.

го. The databank can be found here: <https://www. uspto.gov/trademarks-application-process/searchtrademark-database $>$.

Iг. For a discussion of the history of this football team name, see Smith 20I I; Ver Steeg 2016.

I2. For a legal description and discussion of this evidence, see: Thomas 2014 .

13. According to Hopkins and Joraanstad (2015), the number of mascots with Native American reference has dropped from c. 3000 to less than Iooo. For an excellent discussion of objectionable sport team designators, see Nuessel I994.

14. It is exceedingly rare for an applicants's appeal to result in the reversal of an examining attorney's decision. In an extensive search of the USPTO, Davis was only able to locate one such instance (II 8 ).

\section{Disclosure statement}

No potential conflict of interest was reported by the author.

\section{References}

Battersby, Gregory, and Charles W. Grimes. 20I7. Trademark and Copyright Disputes: Litigation Forms and Analysis. New York: Wolters Kluwer.

Bonadio, Enrico. 2015. "Morality and Public Policy: Some Reflections on the Ban on Registration of Controversial Trademarks." Marquette Intellectual Property Law I9 (I): 43-6I.

Brady, Erik. 20I3, May 9. "Daniel Snyder Say Redskins Will Never Change Name.” USA Today. Accessed June 26, 20I7. https:/www.usatoday.com/story/sports/nfl/redskins/20I3/05/09/washington-redskins-daniel-snyder/ 2I 48 I $27 /$ ? sf I $2629993=$ I.

Chow, Kat. 2017, January I9. "The Slants: Fighting for the Right to Rock a Racial Slur.” National Public Radio. Accessed June 22, 20I7. http://www.npr.org/sections/codeswitch/20I7/0I/I9/510467679/the-slants-fighting-forthe-right-to-rock-a-racial-slur

Forbes Magazine. 2016. Sports Money: 2016 NFL Valuations. Accessed June 24, 20I7. https://www.forbes.com/ nfl-valuations/list/

Freed, Benjamin. 2017, June 19. "Supreme Court's Ruling in Trademark Case is Sure to Help the Redskins." The Washingtonian. Accessed June 2I, 2017. https:/www.washingtonian.com/2017/06/I9/supreme-courts-rulingtrademark-case-sure-help-redskins/ 
Guggenheim, Jack. I999. "Renaming the Redskins (and the Florida State Seminoles?).” Florida State University Law Review 27 (I): 287-320.

Harris, Jamie. 20II, MarchI7. "Rock Band to Trademark Office." Northwest Asian Weekly. Accessed June 24, 20I7. http://nwasianweekly.com/20I I/03/rock-band-to-trademark-office- \%E2 \% 80\% $\% 8$ our-name-is-not-disparaging-to-asians $\% \mathrm{E}_{2} \% 80 \% 99 /$

Heitner, Darren. 2017, June I9. "Supreme Court Ruling is Great for Washington Reskins Trademark Battle." Accessed June 24, 20I7. https://www.forbes.com/sites/darrenheitner/2017/06/I9/supreme-court-ruling-is-greatfor-washington-redskins-in-trademark-battle/\# 564434 ee 39 10

Hinrichsen, Malte. 20I2. Racist Trademarks: Slavery, Orient, Colonialism and Commodity Culture. Berlin: LIT Verlag.

Hopkins, Julie, and Thomas Joraanstad. 201 5. "Challenge-Flag Thrown: The Trademark Trial and Appeal Board's Cancellation of the Redskins' Trademarks and pro-Football's Chances on Appeal.” Journal of Business and Technology Law io (2): 267-296.

Hughey, Rachel. 2004. "The Impact of pro-Football, Inc. V. Harjo on Trademark Protection of Other Marks." Fordham Intellectual Property, Media, and Entertainment Law Journal I4 2: 327-360.

Jeong, Sarah. 2017, January I7. "Should We Able to Reclaim a Racist Insult - As a Registered Trademark?" The New York times. Accessed June 22, 20I7. https://www.nytimes.com/20I7/0I/17/magazine/should-we-be-ableto-reclaim-a-racist-insult-as-a-registered-trademark.html

Kiser, Jessica. 20I I. "How Dykes on Bikes Got It Right.” University of San Francisco Law Review 46 (I): I-36.

Lindsay, Peter. 2008. "Representing Redskins: The Ethics of Native American Team Names." Journal of the Philosophy of Sport 35: 208-224.

National Collegiate Athletic Association (NCAA). 2005. "NCAA Executive Committee Issues Guidelines for Use of Native American Mascots at Championship Events." (Press release). Accessed June 23, 20I7. http://fs.ncaa. org/Docs/PressArchive/2005/Announcements/NCAA \% 2BExecutive \% 2BCommittee \% 2BIssues \% 2BGuidelines $\% 2$ Bfor \% 2BUse \% 2Bof\% 2BNative\% 2BAmerican \% 2BMascots \% 2Bat \% 2BChampionship \% 2 BEvents.html

National Congress of American Indians (NCAI). 20I5, July 8. "Court Upholds Trademark Cancellation." Accessed June 20, 20I7. http://www.ncai.org/news/articles/201 5/07/08/court-upholds-trademark-cancellation

Nuessel, Frank. I994. "Objectionable Sport Team Designators.” Names 42 (2): IOI-I I9.

Phillips, Michael. 2017, June 19. "Supreme Court Rules for Rock Band the Slants, Which Bodes Well for Redskins." Richmond times-Dispatch. Accessed June 23, 2017. http://www.richmond.com/redskins-xtra/supreme-court-rules-forrock-band-the-slants-which-bodes/article_49bd9I 22-498e-507a-a2cc-d $508256 f_{5}$ e 3 b.html

Rasul, Hammad. 2015. "Fourth and Long: The time is Now for the 'Washington Redskins' to Punt the Name." University of Maryland Law Journal of Race, Religion, Gender, and Class. I 4, no. 2: 338-355.

Rowland, Lee. 2017, June I9. "Victory! the Slants Are Officially Rock Stars of the First Amendment." Accessed on I9 June 20I7. Accessed June 23, 20I7. https://www.aclu.org/blog/speak-freely/victory-slants-are-officiallyrock-stars-first-amendment

Smith, Thomas. 20II. Showdown: JFK and the Integration of the Washington Redskins. Boston, MA: Beacon Press.

Stern, Nat. I999. "In Defense of the Imprecise Definition of Commercial Speech." Maryland Law Review 58 (I): $55^{-I} 49$.

Thomas, John. 20I4. "Clear and Convincing Disparagement." Journal of Intellectual Property Law 22 (2): 435-462.

United States District Court for the Eastern District of Virginia: Alexandria Division. 20I 5. "Case No.: I:I4-CvoI043-GBL-IDD.” Pro-Football, Inc., v. Amanda Blackhorse, et al. Accessed June 26, 20I7. http://coop.vaed. uscourts.gov/I I 4cvio43/Document_I6I.pdf

United States Patent and Trademark Office (USPTO). 20I3, November 25. "U.S. Trademark Law: Federal Statutes.” Accessed June 20, 20I7https://www.uspto.gov/sites/default/files/trademarks/law/Trademark_Statutes.pdf

Ver Steeg, Russ. 20I6. "Blackhawk down or Blackhorse down?” Oklahoma Law Review 68 (4): 677-77I.

\section{Notes on contributor}

I. M. Nick holds a BA (Germanics), a BSc (Clinical/Abnormal Psychology), an MA (German Linguistics), an MSc (forensic and Investigative Psychology), a $\mathrm{PhD}$ and the German "Habilitation" (English Linguistics). Her research includes forensic linguistics, language policy, and onomastics. She is the President of the Germanic Society for Forensic Linguistics (GSFL) and the current President of the American Name Society (ANS).

Correspondence to: I. M. Nick, Germanic Society for Forensic Linguistics, Flensburg, Germany. Email: mavi.yaz@web.de 